\title{
Sand and dust storms: underrated natural hazards
}

Nick Middleton Supernumerary Fellow and Lecturer in Geography, St Anne's College, University of Oxford, United Kingdom; Peter Tozer Associate Professor in Farm Management, School of Agriculture and Environment, Massey University, New Zealand; and Brenton Tozer Graduate Student, School of Geography, Environment and Earth Sciences, Victoria University of Wellington, New Zealand

Sand and dust storms (SDS) are wind erosion events typically associated with dryland regions, although they can occur in most environments and their impacts are frequently experienced outside drylands because desert dust haze often is transported great distances. SDS represent hazards to society in numerous ways, yet they do not feature prominently in the disasters literature. This paper considers SDS in a hazard context by examining their ramifications in economic, physical, and social terms, with a focus on agriculture, health, transport, utilities, households, and the commercial and manufacturing sector. There are few assessments of the economic consequences of SDS and those studies that have been conducted lack consistency in data collection methods and analysis. SDS do not result in the significant damage to infrastructure usually associated with many disasters, but the cumulative effects on society can be significant because SDS occur more commonly than most other types of natural hazard.

Keywords: air quality, dust storm, economic impact, health, sand storm, transport, wind erosion

\section{Introduction}

Sand and dust storms (SDS) are atmospheric events typically associated with deserts and semideserts because of the preponderance of dry, unconsolidated substrates with sparse vegetation cover, conditions that facilitate the wind erosion of surface materials. These events represent a significant hazard not only to the inhabitants of dryland regions (Middleton and Sternberg, 2013), but also to the many people who live outside of them because desert dust haze frequently is transported great distances (Kellogg and Griffin, 2006). The consequences for human society are varied and wide-ranging, including threats to health (Zhang et al., 2016), agriculture (Phillips, 1999), electricity generation (Mani and Pillai, 2010), and the transport industry (Baddock et al., 2013). To provide a perspective on the impacts of SDS on society and as a 
natural hazard, research on hospitals in Iran ranked the importance of 10 hazards and their effects: earthquake (71 per cent); extreme temperature (64 per cent); dust storm (59 per cent); hospital overload (48 per cent); power outage (48 per cent); water cut (shortage) (46 per cent); fire (45 per cent); torrential rain (45 per cent); storms (43 per cent); and landslides (39 per cent) (Ardalan et al., 2016). Note that in the context of natural hazards, dust storms follow only earthquakes and heatwaves, but precede torrential rain and other storms, and landslides. These rankings and percentages are specific to conditions in Iran and probably would vary in other countries where SDS may not be as significant as they are in Iran and other countries in west Asia.

Despite their hazardous nature, SDS do not feature prominently in the hazard or disaster literature. However, these atmospheric phenomena are gaining increasing attention at the global policy level. The United Nations General Assembly (UNGA) adopted resolutions on 'combatting sand and dust storms' in 2015 (A/RES/70/195), 2016 (A/RES/71/219) and 2017 (A/RES/72/225), acknowledging that SDS represent a severe impediment to the sustainable development of affected developing countries and the well-being of their peoples. Also in 2016, the second session of the United Nations Environment Assembly adopted a resolution requesting that countries address the challenges posed by SDS through relevant policy measures. A central feature of such policies is SDS management with a major focus on hazard risk reduction, as advocated by the 2015 Sendai Framework for Disaster Risk Reduction (Aitsi-Selmi et al., 2015). This paper considers SDS in a hazard context by examining their ramifications in economic, physical, and social terms.

\section{SDS definitions}

This paper refers to mineral particles that originate from land surfaces, one of many sources of small particulate matter in the atmosphere (others include industrial pollutants, sea salt, and volcanic dust). No strict distinction is made in the definitions of sand and dust storms, since there is a continuum of particle sizes in any storm: clay-sized (less than 4 micrometres $(\mu \mathrm{m})$ ); silt-sized (4 to $62.5 \mu \mathrm{m})$; and sand-sized $(62.5 \mu \mathrm{m}$ to 2 millimetres $(\mathrm{mm})$ ). The World Meteorological Organization (WMO) formally defines a dust storm as the result of winds raising large quantities of dust into the air and reducing visibility at eye level (1.8 metres $(\mathrm{m}))$ to less than $1,000 \mathrm{~m}$, but there is no equivalent formal definition of a sand storm. Nonetheless, WMO synoptic codes for 
present weather (ww) along with associated visibility have been used to produce an internationally standard series of definitions for other dust events (McTainsh and Pitblado, 1987): blowing dust is raised by winds to moderate heights above the ground, reducing visibility at eye level $(1.8 \mathrm{~m})$ but not to less than $1,000 \mathrm{~m}$; dust haze is produced by dust particles in suspended transport that have been raised by a dust storm prior to the time of observation and/or at a great distance away; and dust whirls (or dust devils) are whirling columns of dust moving with the wind and usually are less than $30 \mathrm{~m}$ high (but may extend to $300 \mathrm{~m}$ or more) and of a narrow dimension.

There have been attempts to define the severity of dust events using visibility limits. According to WMO synoptic codes, a severe dust storm has a visibility of less than $200 \mathrm{~m}$, but this is not as widely used as the standard for dust storm (less than 1,000m) and some authorities have adopted alternative visibility limits, such as Iceland (less than 500m, according to DagssonWaldhauserova, Arnalds, and Olafsson, 2013). Other measures of dustiness have also been devised, including the dust storm index, designed to incorporate the frequency and intensity of wind erosion events (O'Loingsigh et al., 2014), and the index of dust weather that reflects atmospheric dustiness, air temperature, and cyclone frequency (Qian, Quan, and Shi, 2002).

Material entrained from a ground surface can be carried by winds over thousands of kilometres from source, regularly across international boundaries, transporting hazardous dust haze to distant locations. Such large-scale dust haze events affect areas measured in tens of thousands and sometimes hundreds of thousands of square kilometres. Sand storms, by contrast, are generally localised events with localised impacts, including sand dune encroachment.

Sand and dust are dominated by quartz, or silicon dioxide $\left(\mathrm{SiO}_{2}\right)$, but may also contain significant amounts of aluminium oxide $\left(\mathrm{Al}_{2} \mathrm{O}_{3}\right)$, iron (III) oxide $\left(\mathrm{Fe}_{2} \mathrm{O}_{3}\right)$, calcium oxide $(\mathrm{CaO})$, and magnesium oxide $(\mathrm{MgO})$, depending on the nature of the source region (Krueger et al., 2004). Many SDS sources also contribute a range of salts, organic matter, pathogenic microorganisms - including bacteria, fungi, and viruses — and anthropogenic pollutants (Goudie and Middleton, 2006).

\section{SDS and hazards}

Natural hazards are normal functions of the natural environment. Inevitably they affect all living organisms, but typically they are only referred to as catastrophes or disasters when they cause 
loss of life, material damage, and social disruption to human society. In short, it is the presence of people that defines whether or not an event results in a disaster. Critical facets of human society that interact with hazards to create disasters include exposure and vulnerability (Mechler et al., 2014), but human action is also reflected in the difficulty frequently faced in distinguishing between purely 'natural' and human-induced events, an issue heightened by the planet's entry into the Anthropocene and understanding of anthropogenic climate change (Waters et al., 2016). SDS add a further dimension to this debate as some sources naturally emit soil particles into the atmosphere while other areas have become sources because of human mismanagement (see below).

The generally low profile of SDS in the hazard or disaster literature is reflected in the fact that neither sand storms nor dust storms appear in the title of any article published in this journal. Furthermore, SDS are not part of some existing databases, such as the World Risk Index used in the World Risk Reports, although they do appear in the classification of disasters employed by the International Disaster Database (EM-DAT).

\section{Dust storm sources and transport pathways}

Several global studies have located the planet's major contemporary desert dust sources by analysing data from terrestrial meteorological stations and several satellite-borne sensors (Prospero et al., 2002; Washington et al., 2003; Ginoux et al., 2012). The largest areas with high dust storm activity are located in desert areas of the Northern Hemisphere, mainly in a broad dust belt that extends from West Africa across the Middle East, to South, Central, and Northeast Asia. The Sahara is widely agreed to be the world's largest dust-producing region (Goudie and Middleton, 2001) and the Bodélé Depression its most active dust source (Bristow, Drake, and Armitage, 2009).

Drylands in the Southern Hemisphere generally emit less dust, although prominent concentrations of wind erosion activity occur in Central Australia, Southern Africa, and the Atacama Desert and Patagonia in South America. These sources produce significant local impacts, as does the North American Great Basin, but they are relatively minor on the global scale, although dust from South American sources frequently is transported to Antarctica (Gili et al., 2016). 
Most of these locations are in the low-latitude drylands, but dust sources occur in almost all environments if conditions are favourable. For instance, dust storms have been recorded on susceptible soils in mid-latitude regions such as Germany (Deetz et al., 2016) and Ukraine (Birmili et al., 2008), and on glacial outwash plains in Alaska, United States (Crusius et al., 2011), Iceland (Dagsson-Waldhauserova, Arnalds, and Olafsson, 2014), and New Zealand (Marx and McGowan, 2005). Indeed, recent studies suggest that some five per cent of global soil dust emissions come from sources in the high latitudes (Bullard, 2017), and some of these sources are not detected in global satellite surveys such as Prospero et al. (2002) and Washington et al. (2003), which used the Total Ozone Monitoring Spectrometer or the more contemporary Moderate Resolution Imaging Spectroradiometer employed by Ginoux et al. (2012).

Quantifying the global mineral dust mass budget is not straightforward because actual measurements are geographically sparse and temporally sporadic. Estimates of annual global dust emissions range from 50-5000 $\mathrm{Tg} \mathrm{yr}^{-1}$ (teragrams per annum), or 0.5-5 billion tonnes (Goudie and Middleton, 2006), although modelling estimates suggest a narrower range of between one and three billion tonnes per annum (see, for example, Mahowald et al., 1999; Miller et al., 2004). However, many of these estimates derived from global models consider only the emission of clay and small silt-sized particles, despite the fact that much larger particulates are frequently involved and, in a growing number of cases, are reported to have been transported considerable distances (Middleton, Betzer, and Bull, 2001; Hladil et al., 2010).

Most of these dust emissions probably come from natural sources (Goudie and Middleton 2006; Ginoux et al., 2012). However, there are also sources that have been significantly influenced by human activities, although the relative contribution of human action to current levels of dust emissions is a subject for debate, with estimates varying from 50 per cent (Tegen, Lacis, and Fung, 1996) to insignificant (Prospero et al., 2002). The calculation by Ginoux et al. (2012) that anthropogenic sources account for 25 per cent of global emissions has been adopted by the United Nations Environment Programme, the WMO, and the United Nations Convention to Combat Desertification (UNEP, WMO, and the UNCCD, 2016).

Dust is deflated from most sources with a marked seasonality. The world's largest source of desert dust, the Bodélé Depression, produces its dust predominantly during a season lasting from October to April, with the Harmattan dust haze affecting much of West Africa and the Gulf of Guinea. Saharan dust is regularly transported along three other main transport paths (Middleton 
and Goudie, 2001): westward over the North Atlantic, to North America and South America; northward across the Mediterranean to southern Europe and sometimes as far north as Scandinavia; and along easterly trajectories across the eastern Mediterranean to the Middle East.

Another major global transport pathway of desert dust is driven by a north-westerly wind known as the Shamal, which affects southern Iraq, Kuwait, southern Iran, and the eastern coast of the Arabian Peninsula typically between February and October (Cao et al., 2015). In northeast Asia, dust from sources in China and Mongolia is transported over the Korean Peninsula and Japan and across the Pacific Ocean during the spring to North America and beyond (Bory, Biscaye, and Grousset, 2003).

Dust trajectories from other, globally less significant, sources have also been traced over great distances. Material from Patagonia has been recovered from ice in Antarctica (McConnell et al., 2007) and dust from Australian deserts is carried across the Tasman Sea to New Zealand (McGowan et al., 2000).

\section{SDS variability through time}

SDS vary in frequency and intensity over a range of timescales beyond their typical seasonality, related to longer-term features of climate variability such as drought and the North Atlantic Oscillation (Goudie and Middleton, 1992; Moulin et al., 1997). Attempts to combat wind erosion with soil conservation measures have succeeded in reducing dust storms in some parts of the world (see, for examples, Fox, Barchyn, and Hugenholtz, 2012; Tan and Li, 2015), but elsewhere marked increases in wind erosion and associated dust storms have been noted. Recent enhanced wind erosion has occurred in the eastern Mediterranean (Ganor et al., 2010), Lower Mesopotamia and adjacent regions (Ghasem et al., 2012), and parts of the Arabian Peninsula (Hsu et al., 2012; Notaro, Yu, and Kalashnikova, 2015) and north-east Asia (Kim, 2008). In some cases, the frequency and intensity of dust storms have increased as a result of human activities, including soil surface disturbance, desertification, and society's excessive use of water. Classic cases of human mismanagement leading to large-scale increases in dust-raising include the notorious Dust Bowl years of the 1930s on the Great Plains of the US when intense drought exposed inappropriate farming practices (McLeman et al., 2014), and the expansion of 
irrigated agriculture in the region of the Aral Sea in Central Asia, making it a major dust source (Issanova et al., 2015).

Anthropogenic activities may also affect dust emissions indirectly, particularly through their effects on climate. Climate change is an important potential driver of future wind erosion and dust storm occurrence, especially via more extreme wind events, greater frequency of droughts, and greater aridity in some areas (Dai, 2010; Field et al., 2012).

\section{SDS hazards}

Sand and dust storms represent hazards for human society in many ways (Middleton, 2017) and these hazards are classified in Table 1 according to the three processes of the wind erosion system: the entrainment, transport, and deposition of fine particles [OK?]. These hazards range from local soil loss and sandblasting of crops to human health issues associated with dust haze and issues related to deposition, such as contamination of soil and water resources. One should note too that SDS present a unique form of natural hazard in that the source and impact regions can be separated by great distances. The geographical extent of SDS hazards has been indicated already, and Middleton and Kang (2017) have surveyed peer-reviewed literature to demonstrate that at least 77 per cent of all parties to the 1996 United Nations Convention to Combat Desertification are directly affected by SDS issues to some extent.

Table 1. Some environmental hazards to human populations caused by wind erosion and dust storms

\begin{tabular}{|l|l|l|}
\hline Entrainment & Transport & Deposition \\
\hline Soil loss & Sandblasting of crops & $\begin{array}{l}\text { Salt deposition and groundwater } \\
\text { salinisation }\end{array}$ \\
\hline Nutrient, seed, and fertiliser loss & Radio communication problems & $\begin{array}{l}\text { Reduction of reservoir storage } \\
\text { capacity }\end{array}$ \\
\hline Crop root exposure & Microwave attenuation & Drinking water contamination \\
\hline Undermining structures & Transport disruption & Burial of structures \\
\hline & Local climatic effects & Crop growth problems \\
\hline & Air pollution & Machinery problems \\
\hline
\end{tabular}




\begin{tabular}{|l|l|l|}
\hline & $\begin{array}{l}\text { Respiratory problems and eye } \\
\text { infections }\end{array}$ & $\begin{array}{l}\text { Reduction of solar power } \\
\text { potential }\end{array}$ \\
\hline & Disease transmission (human) & Electrical insulator failure \\
\hline & $\begin{array}{l}\text { Disease transmission (animals and } \\
\text { plants) }\end{array}$ & Disruption to power supplies \\
\hline
\end{tabular}

Source: Middleton (2017).

\section{Economic impact of SDS hazards}

Sand or dust storms create damage in two locations: the source region (on-site) and the impact region (off-site). The economic impact in either location will depend on many things, such as the level and types of economic activity in either location, the activities undertaken in the source region that may contribute to SDS (that is, cropping or farming), the relative wealth of the population in each location and other determinants of vulnerability, and damage to the environment or ecosystems in either location. Other factors that need to be considered include damage to environmental or ecosystem services in either location, or the human aspects, such as health and income distribution in the source and or impact region.

Hallegatte and Przyluski (2010, p. 2 define a natural disaster from an economic perspective 'as a natural event that causes a perturbation to the functioning of the economic system.' The minimal damage that a dust storm causes to infrastructure in off-site regions can lead people to assume that there is little to no cost in damage to that region, but it has been found that costs are caused by clean-up, loss of production, and health consequences owing to the decrease in air quality. Dust storms do not, in general, cause major damage to infrastructure or structures, but they can lead to disruptions to economic systems, particularly in the impact region(s). These disruptions can occur in many sectors of an economy, such as cultural and historic, manufacturing, transport, tourism, trade, or retail and wholesale. The level of impact will also vary with the amount of activity within the impact region, and within locations within a region. For instance, Tozer and Leys (2013) show that economic impact is somewhat determined by the size of cities and/or towns, and the infrastructure within these locations. Major cities with substantial economic activity, such as transport hubs (airports and/or sea ports) or significant commercial or manufacturing centres, are affected to a higher degree than regional centres or towns/villages where economic activity is relatively low. 
Hallegatte and Pyzyluski (2010) [OK?] define two types of costs associated with natural hazards: direct and indirect. Direct costs are those related to the immediate impact of a natural hazard. In the context of SDS, most costs are direct as the impacts typically are not long term in the same way that damage and reconstruction owing to earthquakes and hurricanes, for instance, leads to longer-term rebuilding of damaged structures, infrastructure, and functions within the economy of the affected area. Indirect costs are those that are imposed on an economy due to business disruptions or other similar ramifications owing to the natural disaster, such as delayed delivery of products because of road or rail closures. However, a single SDS event usually will not have a long term effect on most of the economy. One set of indirect costs that SDS may impose on an economy is connected to the long-term loss of income to landholders in the source region(s) of SDS. Indirect costs may exceed direct costs in some regions. Depending on socioeconomic context, this can have long-term impacts on the regional population, particularly if the costs push a vulnerable populace past a critical threshold.

\section{Onsite costs-source region}

On-site damage typically takes the form of loss of soil and sand, which leads to scalding of the site, and the associated loss of soil nutrients, fertilisers, seeds, and organic matter including soil carbon (Leys and McTainsh, 1994; Leys, 2002). Deflation preferentially removes the finest particles, which is detrimental to soil structure, and which, in turn, reduces soil moisture storage. Many years of research on the effects of wind erosion on agricultural land have demonstrated its significance as a land degradation process: the loss of soil and nutrients reduces the productive capacity of the soil (Larney et al., 1998), and potentially reduces the income of landholders or land users. The impact will vary depending on geographical location, and the economic and political context of the region (ELD Initiative and UNEP, 2015). Furthermore, material eroded can contain soil carbon, which could have a value to the landholder, particularly if in the future carbon sequestration and carbon markets become more fully functional. Additional costs are incurred in the source region owing to damage to infrastructure such as irrigation or water systems, the destruction of telegraph poles, fences, and walls, the loss of livestock and forage for

livestock, sandblasting of crops, and road cleaning.

Huszar and Piper (1986) suggest that an approximation of the immediate on-site costs of wind erosion, such as damage to infrastructure, can be obtained from the off-site costs. Based on 
their calculations, a value of two per cent of the costs of household cleaning can be used as the basis for determining on-site costs. Tozer and Leys (2013), using the proposed method of Huszar and Piper (1986), estimated on-site costs of approximately AUD 5.1 million for a single severe dust storm, dubbed the Red Dawn event, that affected eastern Australia in 2009. However, the method of Huszar and Piper (1986) does not account for the long-term loss in productivity or income owing to soil erosion and soil nutrient loss. The ELD Initiative and the United Nations Environment Programme provide an approach that can measure the loss in production and income because of soil erosion in general (ELD Initiative and UNEP, 2015).

\section{Offsite costs—impact region}

The offsite costs of SDS will depend on many factors; however the principal one will be the level of economic activity in the impact region and the number of sectors of the economy affected. One challenge for researchers studying the economic consequences of SDS is that there are a limited number of studies focusing on the overall impact of SDS on a region or country. Huszar and Piper (1986) estimated the costs of a series of sand and dust storms in the US state of New Mexico only at USD 466 million (in 1984 dollars), with most of the costs incurred by households due to interior cleaning, and landscaping costs, most of which was linked to cleaning the external surfaces surrounding houses. The estimated costs to businesses, retail, wholesale, and services was estimated at USD 7.6 million (in 1984 dollars). Tozer and Leys (2013) estimated the costs to the Australian state of New South Wales of a single severe dust storm at AUD 320 million (in 2011 Australian dollars). The event that caused the interruption to the economy in New South Wales also impacted Queensland, the state north of New South Wales, but the costs to Queensland's economy were not estimated because of funding restrictions.

\section{Health-related consequences}

Dust suspended in the atmosphere has implications for human health owing to its biological, chemical, and physical properties (Goudie, 2014; Zhang et al., 2016). Exposure to dust in the atmosphere can result in conjunctivitis and dermatological disorders, while inhalation can cause respiratory illnesses such as silicosis (or desert lung syndrome) and act as a trigger for many others, including asthma, bronchitis, chronic obstructive pulmonary disease, and emphysema. 
Particle size is the main determinant of where dust comes to rest in the respiratory tract once inhaled and a distinction is commonly highlighted between $\mathrm{PM}_{10}$ particles (particles with a diameter of less than 10 microns), which can penetrate the lungs, and $\mathrm{PM}_{2.5}$ particles (particles with a diameter of less than 2.5 microns), which penetrate deep lung tissue. Various health authorities have issued air-quality guidelines for these two particle size fractions with two components: acceptable atmospheric concentrations at the chronic level (annual mean) and acute level (24-hour mean), although such guideline values are regularly exceeded in, and downwind of, dust source areas. Goudie (2014) shows a large number of desert cities where annual mean $\mathrm{PM}_{10}$ values are an order of magnitude higher than the World Health Organization's guideline and atmospheric concentrations in individual dust events typically are much higher still, even thousands of kilometres from source areas, owing to long-distance, often transboundary, transport (Middleton, 2017).

Many epidemiological studies have shown possible associations of dust exposure with increases in mortality and hospital visits and admissions due to respiratory and cardiovascular diseases. However, despite a great deal of research effort, attributing the individual effects of a variety of factors remains a significant challenge and many questions of causality remain unresolved. One global study that modelled the effects of airborne desert dust on air quality and premature mortality (Giannadaki, Pozzer, and Lelieveld, 2014) concluded that the global proportion of cardiopulmonary deaths caused by $\mathrm{PM}_{2.5}$ desert dust particles was about 1.8 per cent. The proportion was much higher, some 15-50 per cent, for 20 countries in the dust belt.

Desert dust can contain a wide variety of microorganisms capable of causing disease in a range of organisms, such as animals, crop plants, trees, and people (Kellogg and Griffin, 2006). One serious health issue related to West Africa's high atmospheric dust loads is meningococcal meningitis. The incidence of epidemics in the Sahelian zone, otherwise known as the African meningitis belt, appears to be related to Saharan dust intrusions brought by the Harmattan (Thomson, Jeanne, and Djingarey, 2009). Although the causal links remain unclear, Jusot et al. (2016) highlight the seriousness of the issue in the Sahel: 350 million people are at risk across 21 countries.

Major population centres are more affected by SDS simply because of their larger numbers of people, and how such events affect the health of the population and reduces commercial activity (retail and wholesale). The health impacts of SDS are difficult to measure and to assign a 
cost owing to differences in reporting across countries or regions and differences in analysis of data. In a review of 50 papers reporting health effects due to dust or poor air quality, de Longueville et al. (2013) obtained mixed results as to whether or not health was affected by atmospheric dust or poor air quality more generally. One issue that arises in much research related to the health consequences of dust is attribution of effect. For instance, an at-risk portion of the population, especially people with pre-existing cardiopulmonary issues, may have a higher mortality or morbidity rate during a dust storm owing to atmospheric dust exacerbating the preexisting condition. The issue then becomes whether the dust is the cause of the mortality or morbidity or is it the final contributor that leads to the death (de Longueville et al., 2013). Huszar and Piper (1986) estimated that the health costs to households of a series of SDS at approximately USD 19 million out of total household cost budget of USD 458 million. Tozer and Leys (2013) did not find any significant health effects because of the Red Dawn event, but this may be at least partially attributed to an early warning system being in place for at-risk populations. The health costs estimated, though, only encompass the direct cost to households; they do not capture the effects on society of reduced health owing to dust haze.

\section{Transport sector}

Major cities, in comparison to regional centres, tend to have key transport infrastructure such as airports and airline hubs with significantly higher aircraft movements, river or sea ports, and road transport systems. Any factor that limits infrastructure capacity or vehicular movement, therefore, can produce substantial economic losses.

Dust storms can also present dangers to transport and an increase in accidents in the air and on the ground. Poor visibility is a frequent cause, sometimes in combination with the adverse mechanical effects of dust. For these reasons, airports, and on occasion roads and sea ports, are frequently closed during intense dust events. Aircraft that do fly in dusty conditions require more maintenance and the replacement costs of mechanical equipment are higher.

Within the airline industry, aircraft are usually grounded during a severe dust event, and flights may be cancelled, delayed, or diverted to another location. Consequently, airlines will lose income owing to reduced passenger numbers, and some passengers may not travel and require refunds of fares. However, most of the cost to the airline industry is due to increased 
costs, as aeroplanes will need to be diverted if they cannot land at an affected airport; moreover, aeroplanes will need to be repositioned after the dust event to ensure that the schedule returns to normal. In some instances, airlines will provide food and/or accommodation to passengers who are affected by cancellations or delays, or offer alternative means of transport to their final destination (Williams and Young, 1999; Tozer and Leys, 2013). Williams and Young (1999) estimated the median cost of SDS to the air travel industry to be AUD 4.2 million (in 1999 dollars) and Tozer and Leys (2013) estimated the cost to the transport industry of a single major dust storm in New South Wales to be AUD 10.8 million (in 2012 dollars). A key point to note here is that each of these estimates is only for the impact on a single state, and for a single event in the case of Tozer and Leys (2013).

In a national study using reports of air traffic incidents in Australia, Baddock et al. (2013) concluded that atmospheric dust in the country represents at worst an inconvenience and an economic cost; nearly two thirds of the dust-caused air safety issues identified related to navigational problems. There were no reported deaths over the 42-year period studied (19692010) and these authors noted that improvements in aviation technology were at least partly responsible for a reduction in incidents in more recent decades. However, in other parts of the world, where equipment often is older and safety standards may be lower, dust storms have been implicated in a number of aircraft accidents involving fatalities (Middleton, 2017). On roads, fatal accidents are not uncommon when near-zero visibility may manifest very suddenly in association with the arrival of a dust wall. In the US, some 62 deaths nationally were related to dust storms affecting road vehicles between 1980 and 2005 (Ashley and Black, 2008).

Although water transport may not be as severely affected by reduced visibility as the airline industry, ferry and port services may be reduced as a consequence (Tozer, 2012). In addition, port services may be affected by increased loading or unloading times, as surfaces that are covered by dust may be unsafe for work (Al-Hemoud et al., 2017). Increased port processing time could add costs, such as demurrage, to the total costs facing a ship owner or charterer.

For most economies, the impact on the road system can be a significant cost. The effect of SDS on road transport occurs for several reasons: road closures because of either visibility or dust or sand on the road surface; road or traffic accidents owing to surface or visibility conditions; and reduced transport requirements as a flow-on effect of reduced activity in other sectors, such as the construction industry. Dust storms have been shown to lead directly to traffic 
accidents in at least Australia, Germany, Iran, Kuwait, and the US (Burritt and Hyers, 1981; Williams and Young, 1999; Miri et al., 2009; Deetz et al., 2016; Al-Hemoud et al., 2017). However, the economic impact of SDS is difficult to measure, as the costs are due to differences in accidents or accident rates between days with and without dust storms.

Two factors that can affect the costs of road transport are: travel speed during SDS; and the number of vehicles on the road during an event. These aspects affect travel times: travel speed may be reduced because of poor visibility, but if some employees or parents remain at home during a dust storm, the number of vehicles on the road system may be reduced (Tozer and Leys, 2013). Hence, the impacts on travel speed and transport costs may be difficult to estimate.

One other factor contributing to difficulty in estimating the effect on the road transport system is the number of businesses that may shut down or reduce trade during a dust event. Again, this can influence the number of vehicles, such as delivery trucks or vans.

\section{Utility sector}

The deposition of sand and dust can have serious repercussions for the operation of solar power plants (Sarver, Al-Qaraghuli, and Kazmerski, 2013), adversely affecting the two main technologies used: photovoltaic (PV) and concentrating solar-thermal power (CSP) systems. Power can be reduced in PV systems typically by 15-30 per cent in moderate dust conditions, but it can reach 100 per cent if cementation by water soluble salts occurs owing to the combination of dew, very light rain, or humidity with dust. CSP systems are even more sensitive to dust accumulation and require greater maintenance to mitigate deposition. The reliability of power distribution grids in desert areas can also be adversely affected by dust and sand (Maliszewski, Larson, and Perrings, 2012). Such particles frequently carry an electrical charge that interferes with porcelain insulators on high-voltage transmission lines, reducing effective distribution and potentially resulting in flashover outages.

Dust and sand deposition can directly clog streams and drainage channels and decrease reservoir storage capacity, as well as affecting water quality (Riksen and De Graaff, 2001; Arfi, 2003; Reche et al., 2009). The deposition of dust on snow and ice reduces the surface albedo and accelerates melting, and thus affects the timing and magnitude of runoff and meltwater availability (Painter et al., 2010). 


\section{Households}

Dust deposition in households and commercial buildings requires major efforts and entails significant costs with regard to interior and domestic landscaping cleaning (Tozer and Leys, 2013). Previous research has shown that households face the highest direct costs of SDS owing to cleaning of interiors and the exterior, and repairs to and the maintenance of structures and vehicles (Huzsar and Piper, 1986; Tozer and Leys, 2013). Miri et al. (2009) found that household cleaning costs accounted for more than 85 per cent of the total estimated costs of dust storms in the Sistan region of Iran.

\section{Commercial and manufacturing sector}

The manufacturing sector may be affected by SDS if the particulate matter enters the manufacturing facility, or if the material required for production is held up in transit. For instance, electronic component manufacturers in the Republic of Korea noted that more faulty products or faults in final components were observed on days of high atmospheric particulate matter (Kim, 2008).

Another cost of SDS for the commercial sector pertains to absenteeism, or employees being absent to care for children (if schools are closed during a dust event) or others who need assistance. Absenteeism has been shown to reduce productivity, and this decline is a consequence of SDS and therefore must be added to the cost. One point to take into account here is that the only cost that is due to the dust is diminished productivity, not absenteeism, as costs of production should include workers taking leave for various reasons (Tozer and Leys, 2013).

Measuring the economic impact of SDS on the commercial sector is also problematic, since some expenditure that does not taken place during a SDS may happen afterwards, meaning that there is no loss in income to some commercial operators. This is especially true for food and essential item purchases by households, in that the acquisition is simply delayed rather than cancelled, and only delayed for the duration of the event. However, other time-sensitive purchases, such as newspapers, or perishable or fresh foods, such as bread or fruit, may not occur during the event and retailers will lose revenue because of these non-purchases and the product(s) must be discarded. Similarly, discretionary purchases by consumers, such as coffee or fast-food, may not be made, again reducing retailer income on the day of the event (Tozer and Leys, 2013). Other indirect costs may be incurred in the commercial sector owing to delays in 
the delivery of goods required for production or the movement of goods out of production facilities.

\section{Agriculture and ecosystems}

Desert dust deposition can be considerable, with annual rates frequently exceeding $100 \mathrm{t} / \mathrm{km}^{2}$ (metric tons per square kilometre) near major sources (see, for example, Singer et al., 2003; AlAwadhi and AlShuaibi, 2013; Zhang et al., 2017) and declining with distance transported. The deposition of sand and dust has implications for residents both within and beyond desert areas. Such repercussions include encroachment by sand dunes (Ahmady-Birgani et al., 2017), chemical and biological contamination of surface water bodies (Reche et al., 2009), and groundwater (Nativ et al., 1997). Contamination can also occur when saline dusts are deposited on soils (Issanova et al., 2015), and material deposited on plants can have chemical and physical ramifications. Overall, the result usually is decreased productivity, an important outcome for cropland and rangeland.

SDS can impose costs on the agricultural sector through losses in crops, because of plant destruction or yield reductions, and animal production, owing to livestock deaths or lower yields of meat or milk. Ai and Polenske (2008) estimated that the impact of SDS on the agricultural sector in the region of Beijing, China, in 1999 ranked second only to the manufacturing sector, and constituted about 36 per cent of the total cost in that year. Sand or wind blasting can lead to a complete loss of annual crops in a particular region or a reduction in yield. In extreme cases young plants may be totally destroyed, forcing farmers to re-sow their fields (Michels, Sivakumar, and Allison, 1993). The impact on perennial crops could be similar to that on annual crops, in that the current year output could be lost or reduced, but there may also be a longer-run effect on some perennial crops if plants or trees suffer reduced production in future years.

Animal production can be affected in several ways, too. If the system is using animals for milk production, there may be a decrease during SDS, denying the producer of income with no compensatory reduction in costs. The event may lead to the loss of animals, either through death (due to suffocation in particularly severe cases) or animals moving away from the storm and the producer not being able to locate them afterwards, generating a cost. Finally, lost, destroyed, or damaged pasture or forage crops result in the purchase of feedstocks that otherwise would not have occurred [OK?]. 


\section{Other costs}

Other costs of dust storms in the impact region include a reduction in construction and mining activity, owing to health and safety issues at the construction or mining site, and increased emergency service activity, due to road accidents or ambulances having to transport patients with dust-related health problems to hospital. Sand and dust storms can also effect cultural, leisure, and sporting events; the cost to the economy will depend on the type of activity affected. Estimating these costs can sometimes be difficult particularly if the event is a one-off happening such as an outdoor music concert. The closure of schools and educational establishments because of health concerns can also impose costs on the economy, however many of these will be captured in other estimations. The costs of carers remaining at home because of cancelled events will be captured in the absentee estimation and reduced transactions at commercial establishments will be captured in the retail/wholesale sector calculation. Dust deposition also affects outdoor pursuits such as skiing and other snow-related activities when snow is deposited on snow fields (Palmer and Kennedy, 2010; Tozer, 2012), as dust causes faster melting of snow packs, and reduces the 'satisfaction' of skiers or snowboarders.

\section{Accumulation of impacts and costs}

One aspect of dust storms that is significantly different to that of most other natural hazards, with possibly the exception of tropical storms or tornadoes, is their frequency, and their cumulative economic effects [OK?]. Miri et al. (2010) show that the number of days of dust storms in the Sistan region of Iran ranged from 80 to 150 days between 2000 and 2004, with a total duration of 200 to 500 hours of dust. In Mildura in northwest Victoria, Australia, Tozer and Leys (2013) identified three significant dust storms (total suspended particles (TSP) $>1,000 \mu \mathrm{g} \mathrm{m}^{-3}$, or millionth of a gram per cubic meter) and 27 smaller events with TSP between $260 \mu \mathrm{g} \mathrm{m}^{-3}$ and $1,000 \mu \mathrm{m}^{-3}$ that occurred between 1999 and 2012, and estimated the annual cost of SDS in that region alone at AUD 3 million. Miri et al. (2009) estimated that the cumulative cost of sand and dust storms in the Sistan region of Iran between 2000 and 2004 was USD 1.2 billion, most of which was due to household cleaning and increased healthcare costs.

The main issue with respect to measuring the economic impact of SDS is the lack of consistent data collection methods and analysis. Most analyses of SDS are regional and region- 
specific. For example, Huszar and Piper (1986), Williams and Young (1999), Miri, et al., (2009), and Tozer and Leys (2013) all conducted economic evaluations of dust storms in specific states in Australia, Iran, and the US, using, in general, different methods and measuring at times different affected sectors. This approach makes it difficult to make comparisons across studies, even when they are converted to a common currency unit.

\section{Conclusion}

Sand and dust storms, like all natural hazards, represent an obstacle to the sustainable development of affected countries and the well-being of their people. They lead to a disruption in economic and social activity in numerous ways, ranging from soil degradation in agricultural areas to reductions in air quality and visibility that can exacerbate health problems and contribute to misadventure in the road and air transport sectors. Most sectors of a national economy will be affected in some way by SDS owing to the broad-scale events that are typical of these types of storms. Although sand and dust storms do not result in the kind of significant damage to infrastructure that is usually associated with natural hazards, such as earthquakes or hurricanes, the cumulative effects on society can be significant, as they occur more frequently than do other natural hazards. One challenge that arises when attempting to measure the impact(s) of SDS is that each event may affect sectors within society differentially, even if the same location is affected by two events at different times, owing to the nature of activity at the time of the SDS and its severity.

The climatic and physical conditions required for an SDS, such as soil surface cover or wind direction and speed, and the economic impacts of an SDS, have been well researched (as noted above). However, the economic and/or social effects of individual or a series of events on sectors within society and how to mitigate the probability of an SDS are as not well understood, particularly with respect to human-induced factors, such as overgrazing or the diversion of water from sensitive areas. For instance, an area of land that is used by local inhabitants for wood and common grazing can become degraded owing to the loss of vegetative cover, leading to increased wind speed across the soil surface. The simplest solution to this problem is to remove grazing animals and to replant trees, but this would necessitate the relocation of local inhabitants and a reduction in their overall economic and social welfare. Yet, very little research exists on such types of solutions. This presents challenges to policymakers, as they do not have sufficient 
information on which to base policy, but also opportunities for researchers to develop programmes to measure and understand the impact of SDS on discrete segments of the affected population.X

\section{Correspondence}

Peter Tozer, Associate Professor, Institute of Agriculture and Environment, Massey University, Palmerston North, 4442, New Zealand. Telephone: +64 (06) 3569099 (ext. 84795); e-mail:

P.Tozer@massey.ac.nz

\section{References}

Ahmady-Birgani, H., K.G. McQueen, M. Moeinaddini, and H. Naseri (2017) 'Sand dune encroachment and desertification processes of the Rigboland Sand Sea, Central Iran'. Scientific Reports. 7(1). Article 1523. https://www.nature.com/articles/s41598-017-01796-Z (last accessed on 31 October 2018).

Ai, N. and K.R. Polenske (2008) 'Socioeconomic impact analysis of yellow-dust storms: an approach and case study for Beijing'. Economic Systems Research. 20(2). pp. 187-203.

Aitsi-Selmi, A., S. Egawa, H. Sasaki, C. Wannous, and V. Murray (2015) 'The Sendai Framework for Disaster Risk Reduction: renewing the global commitment to people's resilience, health, and well-being'. International Journal of Disaster Risk Science. 6(2). pp. 164-176.

Al-Awadhi, J. M., and A. A. AlShuaibi (2013) 'Dust fallout in Kuwait city: deposition and characterization'. Science of the Total Environment. 461-462 (September). pp 139-148.

Al-Hemoud, A., M. Al-Sudairawi, S. Neelamanai, A. Naseeb, and W. Behbehani (2017) 'Socioeconomic effect of dust storms in Kuwait'. Arabian Journal of Geosciences. 10(1). Article 18. https://link.springer.com/article/10.1007/s12517-016-2816-9 (last accessed on 31 October 2018).

Ardalan, A. et al. (2016) '2015 estimation of hospitals safety from disasters in I.R. Iran: the results from the assessment of 421 hospitals'. PLoS One. 11(9). Article e0161542. https://journals.plos.org/plosone/article?id=10.1371/journal.pone.0161542 (last accessed on 31 October 2018). 
Arfi, R. (2003) 'The effects of climate and hydrology on the trophic status of Sélingué Reservoir, Mali, West Africa'. Lakes and Reservoirs: Research and Management. 8(3-4). pp. 247-257.

Ashley, W.S. and A.W. Black (2008) 'Fatalities associated with nonconvective high-wind events in the United States'. Journal of Applied Meteorology and Climatology. 47(2). pp. $717-725$.

Baddock, M.C., C.L. Strong, P.S. Murray, and G.H. McTainsh (2013) ‘Aeolian dust as a transport hazard'. Atmospheric Environment .71 (June). pp. 7-14.

Birmili, W. et al. (2008) 'A case of extreme particulate matter concentrations over Central Europe caused by dust emitted over the southern Ukraine'. Atmospheric Chemistry and Physics. 8(4). pp. 997-1016.

Bory, A.J.M., P.E. Biscaye, and F.E. Grousset (2003) 'Two distinct seasonal Asian source regions for mineral dust deposited in Greenland (NorthGRIP)'. Geophysical Research Letters. 30(4). https://agupubs.onlinelibrary.wiley.com/doi/full/10.1029/2002GL016446 (last accessed on 31 October 2018).

Bristow, C.S., N. Drake, and S. Armitage (2009) 'Deflation in the dustiest place on Earth: the Bodélé Depression, Chad'. Geomorphology. 105(1). pp. 50-58.

Bullard, J.E. (2017) 'The distribution and biogeochemical importance of high-latitude dust in the Arctic and Southern Ocean-Antarctic regions'. Journal of Geophysical Research: Atmospheres. 122(5). pp. 3098-3103.

Burritt, B.E. and A. Hyers (1981) 'Evaluation of Arizona's highway dust warning system'. Geological Society of America Special Papers. Number 186. pp. 281-292.

Cao, H., F. Amiraslani, J. Liu, and N. Zhou (2015) 'Identification of dust storm source areas in West Asia using multiple environmental datasets'. Science of the Total Environment. 502 (January). pp. 224-235.

Crusius, J. et al. (2011) 'Glacial flour dust storms in the Gulf of Alaska: hydrologic and meteorological controls and their importance as a source of bioavailable iron'. Geophysical Research Letters. 38(6). https://agupubs.onlinelibrary.wiley.com/doi/full/10.1029/2010GL046573 (last accessed on 31 October 2018). 
Dagsson-Waldhauserova, P., O. Arnalds, and H. Olafsson (2013) 'Long-term frequency and characteristics of dust storm events in Northeast Iceland (1949-2011)'. Atmospheric Environment. 77 (October). pp. 117-127.

Dagsson-Waldhauserova, P., O. Arnalds, and H. Olafsson (2014) 'Long-term variability of dust events in Iceland (1949-2011)'. Atmospheric Chemistry and Physics. 14(24). pp. 1341113422 .

Dai, A. (2010). 'Drought under global warming: a review'. WIREs: Climate Change. 2(1). pp. 45-65.

de Longueville, F., P. Ozer ,S. Doumbia, and S. Henry (2013) 'Desert dust impacts on human health: an alarming worldwide reality and a need for studies in West Africa'. International Journal of Biometeorology. 57(1). pp. 1-19.

Deetz, K., M. Klose, I. Kirchner, and U. Cubasch (2016) 'Numerical simulation of a dust event in northeastern Germany with a new dust emission scheme in COSMOART'. Atmospheric Environment. 126 (February). pp. 87-97.

ELD Initiative and UNEP (United Nations Environment Programme) (2015) The Economics of Land Degradation in Africa: Benefits of Action Outweigh the Costs. October. http://www.eld-initiative.org/fileadmin/pdf/ELD-unep-report_07_spec_72dpi.pdf (last accessed on 31 October 2018).

Field, C.B. et al. (eds.) (2012) Managing the Risks of Extreme Events and Disasters to Advance Climate Change Adaptation. A special report of Working Groups I and II of the Intergovernmental Panel on Climate Change. Cambridge University Press, Cambridge.

Fox, T.A., T.E. Barchyn, and C.H. Hugenholtz (2012) 'Successes of soil conservation in the Canadian Prairies highlighted by a historical decline in blowing dust'. Environmental Research Letters. 7(1). http://iopscience.iop.org/article/10.1088/17489326/7/1/014008/meta (last accessed on 31 October 2018).

Ganor, E., I. Osetinsky, A. Stupp, and P. Alpert (2010) 'Increasing trend of African dust, over 49 years, in the eastern Mediterranean'. Journal of Geophysical Research-Atmospheres. 115(D7). https://agupubs.onlinelibrary.wiley.com/doi/full/10.1029/2009JD012500 (last accessed on 31 October 2018).

Ghasem, A., A. Shamsipour, M. Miri, and T. Safarrad (2012) 'Synoptic and remote sensing analysis of dust events in southwestern Iran'. Natural Hazards. 64(2). pp. 1625-1638. 
Giannadaki, D., A. Pozzer, and J. Lelieveld (2014) 'Modeled global effects of airborne desert dust on air quality and premature mortality'. Atmospheric Chemistry and Physics. 14(2). pp. 957-968.

Gili, S. et al. (2016) 'Provenance of dust to Antarctica: a lead isotopic perspective'. Geophysical Research Letters. 43(5). pp. 2291-2298.

Ginoux, P., J.M. Prospero, T.E. Gill, N.C. Hsu, and M. Zhao (2012) 'Global-scale attribution of anthropogenic and natural dust sources and their emission rates based on MODIS Deep Blue aerosol products'. Reviews of Geophysics. 50(RG3005). https://ntrs.nasa.gov/archive/nasa/casi.ntrs.nasa.gov/20140010536.pdf (last accessed on 31 October 2018).

Goudie, A.S. (2014) 'Desert dust and human health disorders'. Environment International. 63 (February). pp. 101-113.

Goudie, A.S. and N.J. Middleton (1992) 'The changing frequency of dust storms through time'. Climatic Change. 20(3). pp. 197-225.

Goudie, A.S. and N.J. Middleton (2001) 'Saharan dust storms: nature and consequences'. Earth-Science Reviews. 56(1). pp. 179-204.

Goudie, A.S. and N.J. Middleton (2006) Desert Dust in the Global System. Springer Science, Heidelberg.

Hallegatte, S. and V. Przyluski. (2010) The Economics of Natural Disasters: Concepts and Methods. Policy Research Working Paper 5507. The World Bank, Washington, DC.

Hladil, J. et al. (2010) 'Dust - A geology-orientated attempt to reappraise the natural components, amounts, inputs to sediment, and importance for correlation purposes'. Geologica Belgica. 13(4). pp. 367-384.

Hsu, N.C. et al. (2012) 'Global and regional trends of aerosol optical depth over land and ocean using SeaWiFS measurements from 1997 to 2010'. Atmospheric Chemistry and Physics. 12(17). pp. 8037-8053.

Huszar, P.C. and S.L. Piper (1986) 'Estimating the off-site costs of wind erosion in New Mexico'. Journal of Soil and Water Conservation. 41(6). pp. 414-416.

Issanova, G., J. Abuduwaili, O. Galayeva, O. Semenov, and T. Bazarbayeva (2015) 'Aeolian transportation of sand and dust in the Aral Sea region'. International Journal of Environmental Science and Technology. 12(10). pp. 3213-3224. 
Jusot, J.F. et al. (2016) 'Airborne dust and high temperatures are risk factors for invasive bacterial disease'. Journal of Allergy and Clinical Immunology. 139(3). pp. 977-986.

Kellogg, C.A. and D.W. Griffin (2006) 'Aerobiology and the global transport of desert dust'. Trends in Ecology and Evolution. 21(11). pp. 638-644.

Kim J. (2008) 'Transport routes and source regions of Asian dust observed in Korea during the past 40 years (1965-2004)’. Atmospheric Environment. 42(19). pp. 4778-4789.

Krueger, B. J., V.H. Grassian, J.P. Cowin, and A. Laskin (2004) 'Heterogeneous chemistry of individual mineral dust particles from different dust source regions: the importance of particle mineralogy'. Atmospheric Environment. 38(36). pp. 6253-6261.

Larney, F.J., M.S. Bullock, H.H. Janzen, B.H. Ellert, and E.C. Olson (1998) 'Wind erosion effects on nutrient redistribution and soil productivity'. Journal of Soil and Water Conservation. 53(2). pp. 133-140.

Leys, J. (2002) 'Erosion by wind, effects on soil quality and productivity'. Encyclopedia of Soil Science. Marcel Dekker, New York, NY. pp. 499-502.

Leys, J.F. and G.H. McTainsh (1994) 'Soil loss and nutrient decline by wind erosion - Cause for concern'. Australian Journal of Soil and Water Conservation. 7(3). pp. 30-40.

Mahowald, N. et al. (1999) 'Dust sources and deposition during the last glacial maximum and current climate: a comparison of model results with paleodata from ice cores and marine sediments'. Journal of Geophysical Research-Atmospheres. 104(D13). pp. 15895-15916.

Maliszewski, P.J., E.K. Larson, and C. Perrings (2012) 'Environmental determinants of unscheduled residential outages in the electrical power distribution of Phoenix, Arizona'. Reliability Engineering and System Safety. 99 (March). pp. 161-171.

Mani, M. and R. Pillai (2010) 'Impact of dust on solar photovoltaic (PV) performance: research status, challenges and recommendations'. Renewable and Sustainable Energy Reviews. 14(9). pp. 3124-3131.

Marx, S.K. and H.A. McGowan (2005) 'Dust transportation and deposition in a superhumid environment, west coast, South Island, New Zealand'. Catena. 59(2). pp. 147-171.

McConnell, J.R., A.J. Aristarain, J.R. Banta, P.R. Edwards, and J.C. Simões (2007) '20thcentury doubling in dust archived in an Antarctic Peninsula ice core parallels climate change and desertification in South America'. Proceedings of the National Academy of Sciences. 104(14). pp. 5743-5748. 
McGowan, H.A., G.H. McTainsh, P. Zawar-Reza, and A.P. Sturman (2000) 'Identifying regional dust transport pathways: application of kinematic trajectory modelling to a transTasman case'. Earth Surface Processes and Landforms. 25(6). pp. 633-647.

McLeman, R.A. et al. (2014) 'What we learned from the Dust Bowl: lessons in science, policy, and adaptation'. Population and Environment. 35(4). pp. 417-440.

McTainsh, G.H. and J.R. Pitblado (1987) 'Dust storms and related phenomena measured from meteorological records in Australia'. Earth Surface Processes and Landforms. 12(4). pp. $415-424$.

Mechler, R. et al. (2014) 'Managing unnatural disaster risk from climate extremes'. Nature Climate Change. 4(4). pp. 235-237.

Michels, K., M.V.K. Sivakumar, and B.E. Allison (1993) 'Wind erosion in the southern Sahelian zone and induced constraints to pearl millet production'. Agriculture and Forest Meteorology. 67(1-2). pp. 65-77.

Middleton, N.J. (2017) 'Desert dust hazards: a global review'. Aeolian Research. 24 (February). pp. 53-63.

Middleton, N.J., P.R. Betzer, and P.A. Bull (2001) 'Long-range transport of "giant" aeolian quartz grains: linkage with discrete sedimentary sources and implications for protective particle transfer'. Marine Geology. 177(3). pp. 411-417.

Middleton, N.J. and A.S. Goudie (2001) 'Saharan dust: sources and trajectories'. Transactions of the Institute of British Geographers. 26(2). pp. 165-181.

Middleton, N.J. and T. Sternberg (2013) 'Climate hazards in drylands: a review'. Earth-Science Reviews. 126 (November). pp. 48-57.

Middleton, N.J. and U. Kang (2017) 'Sand and dust storms: impact mitigation'. Sustainability. 9(6). Article 1053. https://www.mdpi.com/2071-1050/9/6/1053/htm (last accessed on 31 October 2018).

Miller R.L., I. Tegen, and J. Perlwitz (2004) 'Surface radiative forcing by soil dust aerosols and the hydrologic cycle'. Journal of Geophysical Research - Atmospheres. 109(D4). https://agupubs.onlinelibrary.wiley.com/doi/abs/10.1029/2003JD004085 (last accessed on 31 October 2018). 
Miri, A., A. Hasan, M.R. Ekhtesasi, N. Panjehkeh, and A. Ghanbari (2009) 'Environmental and socio-economic impacts of dust storms in Sistan region, Iran'. International Journal of Environmental Studies. 66(3). pp. 343-355.

Miri, A., A. Moghaddamnia, A. Pahlavanravi, and N. Panjehkeh (2010) 'Dust storm frequency after the 1999 drought in the Sistan region, Iran'. Climate Research.41(1). pp. 83-90.

Moulin, C., C.E. Lambert, F. Dulac, and U. Dayan (1997) 'Control of atmospheric export of dust from North Africa by the North Atlantic Oscillation'. Nature. 387(6634). pp. 691-694.

Nativ, R., E. Adar, O. Dahan, and I. Nissim (1997) 'Water salinization in arid regionsobservations from the Negev desert, Israel'. Journal of Hydrology. 196(1). pp. 271-296.

Notaro, M., Y. Yu, and O.V. Kalashnikova (2015) 'Regime shift in Arabian dust activity, triggered by persistent Fertile Crescent drought'. Journal of Geophysical ResearchAtmospheres. 120(10). pp. 229-249.

O'Loingsigh, T. et al. (2014) 'The dust storm index (DSI): a method for monitoring broadscale wind erosion using meteorological records'. Aeolian Research. 12 (October). pp.29-40.

Painter, T.H. et al. (2010) 'Response of Colorado River runoff to dust radiative forcing in snow'. Proceedings of the National Academy of Sciences. 107(40). pp. 17125-17130.

Palmer, J. and C. Kennedy (2010) 'Dust on snow reduces Colorado river flow'. Climate.gov. 5 October. https://www.climate.gov/news-features/featured-images/dust-snow-reducescolorado-river-flow (last accessed on 31 October 2018).

Phillips, S.T. (1999) 'Lessons from the dust bowl: dryland agriculture and soil erosion in the United States and South Africa, 1900-1950'. Environmental History. 4(2). pp. 245-266.

Prospero, J.M., P. Ginoux, O. Torres, S.E. Nicholson, and T.E. Gill (2002) 'Environmental characterization of global sources of atmospheric soil dust identified with the NIMBUS-7 TOMS absorbing aerosol product'. Reviews of Geophysics. 40(1). pp. 2-1-2-31.

Qian, W., L. Quan, and S. Shi (2002) 'Variations of the dust storm in China and its climatic control'. Journal of Climate. 15(10). pp. 1216-1229.

Reche, I. et al. (2009) 'Effect of Saharan dust inputs on bacterial activity and community composition in Mediterranean lakes and reservoirs'. Limnology and Oceanography. 54(3). pp. 869-879.

Riksen, M.J.P.M. and J. De Graaff (2001) 'On-site and off-site effects of wind erosion on European light soils'. Land Degradation and Development. 12(1). pp. 1-11. 
Sarver, T., A. Al-Qaraghuli, and L.L. Kazmerski (2013) 'A comprehensive review of the impact of dust on the use of solar energy: history, investigations, results, literature, and mitigation approaches'. Renewable and Sustainable Energy Review. 22 (June). pp. 698733.

Singer A., E. Ganor, S. Dultz, and W. Fischer (2003) 'Dust deposition over the Dead Sea'. Journal of Arid Environments. 53(1). pp. 41-51.

Tan, M. and X. Li (2015) 'Does the Green Great Wall effectively decrease dust storm intensity in China? A study based on NOAA NDVI and weather station data'. Land Use Policy. 43 (February). pp. 42-47.

Tegen I., A. Lacis, and I. Fung (1996) 'The influence of mineral aerosols from disturbed soils on the global radiation budget'. Nature. 380(6573). pp. 419-422

Thomson, M.C., I. Jeanne, and M. Djingarey (2009) 'Dust and epidemic meningitis in the Sahel: a public health and operational research perspective'. IOP Conference Series: Earth and Environmental Science. 7(1). Article 012017.

http://iopscience.iop.org/article/10.1088/1755-1307/7/1/012017 (last accessed on 31 October 2018).

Tozer, P. (2012) Economic Impact of Off Site Wind Erosion: Final Report Project. Lower Murray Darling Catchment Management Authority, Buronga, NSW.

Tozer, P. and J. Leys (2013) 'Dust storms - What do they really cost?'. The Rangeland Journal. 35(2). pp. 131-142.

UNEP (United Nations Environment Programme), WMO (World Meteorological Organization), and UNCCD (United Nations Convention to Combat Desertification) (2016) Global Assessment of Sand and Dust Storms. UNEP, Nairobi.

Washington, R., M. Todd, N.J. Middleton, and A.S. Goudie (2003) 'Dust-storm source areas determined by the total ozone monitoring spectrometer and surface observations'. Annals of the Association of American Geographers. 93(2). pp. 297-313.

Waters, C.N. et al. (2016) 'The Anthropocene is functionally and stratigraphically distinct from the Holocene'. Science. 351(6269). Article 2622. http://science.sciencemag.org/content/351/6269/aad2622 (last accessed on 31 October 2018). 
Williams, P. and M. Young (1999) Costing Dust: How Much Does Wind Erosion Cost the People of South Australia. Final report. August. Land and Water, Policy and Economic Research Unit, Commonwealth Scientific and Industrial Research Organisation, Adelaide, SA.

Zhang, X. et al. (2016) 'A systematic review of global desert dust and associated human health effects'. Atmosphere. 7(12). https://www.mdpi.com/2073-4433/7/12/158/htm (last accessed on 31 October 2018).

Zhang, X. et al. (2017) 'Dust deposition and ambient PM 10 concentration in northwest China: spatial and temporal variability'. Atmospheric Chemistry and Physics. 17(3). pp. 16991711. 